Business education in Hong Kong after 1997

Chi-Kim Cheung

Journal of Education for Business; Jul/Aug 1998; 73, 6; ABI/INFORM Global pg. 333

\title{
Business Education in Hong Kong After 1997
}

CHI-KIM CHEUNG

Hong Kong University

Pokfulam, Hong Kong
B usiness education in Hong Kong first appeared in the form of vocational subjects designed to produce the technical and secretarial manpower necessary for the growing economy. But recent social changes and Hong Kong's return to China after 1997 call for a new form of business education in secondary schools.

In planning the business curriculum, developers must foresee what is expected in the business. In this article, I discuss the challenge of developing a business curriculum adequate to the economic and social needs of Hong Kong.

\section{Economic Change in Society}

In recent years, a continuous decline in primary and secondary production has changed the structure of Hong Kong's economy, shifting its emphasis from the manufacturing industries and entrepot trade to financial activities. The tertiary sector has grown rapidly, employing more workers than all the other sectors. In 1995, more than $72 \%$ of Hong Kong's economic activity was produced by the tertiary sector. In Table 1, I illustrate the distribution of the workforce in the past 3 decades.

These economic trends have implications for business education in Hong

\begin{abstract}
Recent global economic changes and Hong Kong's return to mainland China after 1997 have created a demand for a new form of business education in Hong Kong secondary schools. To assure a leadership role for Hong Kong in the future world economy, Hong Kong's secondary schools must take steps to separate vocational and business education and incorporate international issues, information technology, attitude development, and ethics into the business curriculum.
\end{abstract}

Kong. Training in the rapidly declining primary and secondary sectors is becoming less necessary; meanwhile, Hong Kong must provide leadership for the increased business activities in the tertiary sector. It should view its role as China's business center, much like Manhattan in the United States.

Hong Kong must continue to be the preferred location for skills required in financial services. To maintain its leadership, it must begin providing quality business education in secondary schools and continue to train and equip students with the skills and services required by international companies. Business education in Hong Kong must produce business leaders who are competitive and compatible.

Hong Kong's return to China in 1997 was intended to increase its competitiveness through better access to resources and land in China. Hong Kong will likely become a service center for the economy of southern China, while continuing to provide services in banking, financing, accounting, trade, and marketing to China.

Hong Kong will continue to be a business center, making use of its telecommunications system and integrating its service economy with south China's manufacturing base, thereby becoming the nucleus for planning while China provides manpower and production. To achieve this, Hong Kong needs a business curriculum with a vision matching the needs of its future society. In short, business education in Hong Kong secondary schools should no longer see its role as training clerks and secretaries, but as paving the way for students who will assume leadership roles in the developing business sector.

\section{The Separation of Business Education From Vocational Education}

Because business education in Hong Kong secondary schools was first established to provide training for the low sector of the labor market and for the prevocational schools, its depth and breadth are questionable. It is not designed for those who want to acquire 
TABLE 1. Distribution of the Workforce by Economic Sector (\%)

\begin{tabular}{lccc}
\hline \hline Year & Primary & Secondary & Tertiary \\
\hline 1961 & 8.1 & 48.9 & 43.0 \\
1971 & 4.3 & 53.6 & 42.1 \\
1981 & 2.0 & 49.8 & 48.2 \\
1991 & 0.8 & 36.7 & 62.5 \\
1995 & 0.6 & 27.1 & 72.3 \\
\hline
\end{tabular}

deep knowledge and understanding of the subjects. Thus, the status of business education in Hong Kong secondary schools is low; it is said that only the students with less ability will study business education.

Should business education continue to be treated as only a preparation for support roles in business, preparing students for repetitive, low-wage employment, or should it be a part of general education? Two curricula may need to be developed: one for vocational education, in which business subjects provide the necessary facts and knowledge to those who may not further their studied, and another as part of a general education that would provide a clear route and goals for business education. Students taking the second type of curriculum would be prepared for a tertiary education, which would provide the knowledge and skills necessary for becoming business professionals.

\section{Internationalization of Materials}

Thanopoulos (1986, p. 4) pointed out that "of foremost significance is the ability to adapt to other people's turfs, to know the rules of their games, their cultures, their languages, and the international ethics." An internationalized business curriculum should thus be considered. The University of Hong Kong has already established an international MBA program to provide students with an understanding of the different managerial and business practices in Asia and the way in which those may differ from Western ones. Further, the strengths and weaknesses of Western managerial theories are evaluated and integrated for application to Asian business practices. The international MBA gives students an understanding of the impact of the increasing international- ization of business on the Asia-Pacific region.

At the secondary level, business education should provide students with a basic international perspective. The use of case studies from different countries will expose students to different business systems with varied practices in different places. Students will become more globally aware and internationally competitive, increasing their chances of success in the future.

\section{Inclusion of Information Technology in the Business Curriculum}

Many countries have become aware of the importance of information technology (IT) and have begun to apply a considerable portion of their budgets to it. According to Wang's study (1994), the national expenditure on IT as a percentage of GNP is relatively high in the United States (3.5\%), Japan (2\%), South Korea $(1.3 \%)$, and Singapore $(1.7 \%)$. Those countries aim to promote better exploitation of IT for global expansion.

Unfortunately, though we are approaching the end of the 20th century, there is still no proper IT coverage in Hong Kong secondary schools. Educators, especially those in business education, should equip graduates with the indispensable skills to apply IT in business. IT must be incorporated into the business curriculum of secondary schools at the policy level, and resources such as computers and training courses for business teachers must be provided.

\section{Attitude Training}

Besides teaching students skills and knowledge, secondary business education should also focus on productive work habits and attitude development (Ober, 1989). Brumley, Pollard, and Yopp (1993) found that graduates of secondary schools should be expected to possess skills in decisionmaking, human relations, and self-management, among others. Renwick (1992) expected Hong Kong graduates to possess communication skills and interpersonal sensitivity, factors that are as important as the business skills and knowledge they acquire from schools. This holds especially true for Hong Kong, where tertiary production dominates and the majority of workers are engaged in producing services.

In reality, many employers are disappointed by their employees: "Young people lack discipline; they expect to be catered to; they do not want to do the dirty jobs; they do not respect authority ... they can't make change; they do not understand the importance of providing customer service" (Zemsky, 1994, p. 5). Employers in Hong Kong report that many graduates today do not have a good work attitude (Cheung, 1996) and are inconsiderate, insensitive, and irresponsible. These attitudes could reduce their chances for employment, while negatively affecting Hong Kong's competitive ability. A good secondary business curriculum must strike a balance between skills and knowledge and the less tangible attitudes that students pick up from courses.

\section{The Teaching of Ethics in Business Education}

A major purpose of business education is to help students become effective, well-informed citizens who understand what is going on around them. This involves the making of value judgments. The increasing complexity and scale of business practice has left many searching for ethical guidelines and reassurance. It is essential that students taking business education think through the ethical implications of the various aspects of business practice before they become practitioners and encounter the complex issues of the future marketplace.

Students today are exposed to this materialistic world earlier, and they are constantly confronted by ethical issues. We cannot assume that they will learn 
how to deal with these problems if ethics is not taught formally. Because ethics is not part of the academic discipline. it is treated negligibly in the curriculum. Research done recently by the Independent Commission Against Corruption (ICAC, 1996) suggested that university graduates in business were willing to act unethically to maximize their own interest.

Another survey done by Oxfam found that secondary school students in Hong Kong placed self-interest over other virtues in importance (Economic Times, 1996). The result is not surprising: people in Hong Kong are often labeled as money-minded, placing their self-interest over moral issues. Teaching ethics in business education is essential because unethical practices such as abuse of sick leave, accepting bribes, and employee theft can cost a company a great deal. The teaching of values in business education forces decisionmaking and analysis into dimensions be- yond individual interests. It is consciousness raising, in which students are trained not to see their own interests only, but the needs of society also.

\section{Conclusion}

Education reflects society and society shapes education. At the current stage of economic and political transformation, Hong Kong urgently needs to train business students who will have the vision, skills, and knowledge to lead Hong Kong into the 21 st century. Business education in Hong Kong secondary schools must go beyond producing adequate manpower for low-wage jobs. It is time to reflect on how changes in curriculum and resource allocation can serve the best interest of Hong Kong. It must act now to excel in the future.

\section{REFERENCES}

Brumley. D.. Pollard, C. \& Yopp. M. C. (1993). Views, beliefs and opiaions of secondary busi- ness education by state employment service managers and secondary principals in the Pacific Northwest. Delta Pi Epsilon Joumal, 35(1), $39-50$.

Cheung, C. K. (1996). Report on the Special Group on Business Education in Hong Kong. In C. K. Cheung \& D. B. Lewis (Eds.), Proceedings of the Conference on Business and Education: Curriculum change and development, Hong Kong.

Economic Times (in Chinese). (1996, March 13). A report on students' value. pp. --

Hong Kong Government. (1996). Hong Kong. Hong Kong: Government Printer.

Independent Commission Against Corruption (ICAC). (1996). Work ethics of young people. Hong Kong: Hong Kong Ethics Development Centre.

Ober, S. (1989). Business education: Defining our discipline. Business Education Forum, November, pp. 3-10.

Renwick. B. (1992). What business expects of education. Curriculum Forum, 2(1), 1-3.

Thanopoulos, J. (Ed.). (1986). International business curriculum: A global survey: Cleveland: Academy of International Business.

Wang. P. (1994). Information systems management issues in the Republic of China for 1990s. Information Management, pp. 341-352.

Zemsky, R. (1994). What employers want: Employer perspectives on youth, the youth labour market, and prospects for a national system of youth apprenticeships. Philadelphia. PA: National Center on the Educational Quality of the workforce.

\section{Advertise in the \\ Journal of Education for Business}

For more information please contact:

L. Grant Williams, Advertising Production Manager

Heldref Publications

1319 Eighteenth St., NW

Washington, DC 20036-1802

Phone: (202) 296-6267 • Fax: (202) 296-5149 